\title{
PROMISSORY ESTOPPEL IN A PRIVATE NON-LABOUR ARBITRATION
}

\author{
W.H. HURLBURT*
}

The purpose of this note is to inquire whether, in Alberta, an arbitrator in a non-labour consensual arbitration may be entitled to apply a promissory estoppel in order to reach his decision and provide a foundation for his award. Two recent judgments of the Alberta Court of Appeal suggest that the answer is affirmative. They are Smoky River Coal Limited v. United Steelworkers of America' ${ }^{\prime}$ and Alberta Union of Provincial Employees v. Alberta ${ }^{2}$.

In each of the two cases, an employer had discontinued a practice of conferring specific benefits which the collective agreement did not require it to confer. In each of the two cases, the union claimed that the employer's actions in conferring the benefits estopped the employer from discontinuing the benefits. In each of the two cases the basis of the decision of the Court of Appeal was that the facts did not give rise to a promissory estoppel.

In the Smoky River case, the arbitrator had decided (wrongly, in the Court of Appeal's view) that the employer was estopped from discontinuing the benefit in question. Upon the application for certiorari, Mr. Justice Bowen reviewed authorities, including Hughes v. Metropolitan Railway ${ }^{3}$, which show that promissory estoppel is an equitable doctrine that is applied by superior courts of equity which have plenary jurisdiction. He then referred to authority for the proposition that "inferior statutory tribunals" have only the powers which the statute has conferred expressly or by necessary implication. "Therefore", he said, "while a Superior Court in Alberta may make a finding of promissory estoppel in an exercise of its equitable jurisdiction, it is not clear how an inferior tribunal may do so." He then reviewed the statutory provisions which conferred power on the arbitrator and concluded that they did not confer the power to apply a promissory estoppel, and granted certiorari on that ground.

In the Court of Appeal, Mr. Justice Stevenson said that he had "grave reservations about the proposition that an arbitrator cannot apply socalled equitable principles in carrying out his obligations". However, because he had concluded that the arbitrator had made a fundamental error in applying the doctrine of promissory estoppel, he found it

- Director Emeritus and consultant, Institute of Law Research and Reform and of Counsel, Reynolds, Mirth, Richards and Farmer, Edmonton.

1. (1985) 60 A.R. 36.

2. (1987) 77 A.R. 271. A number of recent arbitrators' decisions have applied the doctrine of promissory estoppel: See Adjudication between AUPE and Govt. of Alberta re 1985-86 Class Contact Hours at AVC-Calgary, (Nov. 24, 1987; Jones, Unreported). This note will restrict itself to the Court of Appeal decisions.

3. [1877] 2 A.C. 438 (H.L.). 
"unnecessary to state a conclusion on this issue". The appeal was accordingly dismissed, not on the grounds that the arbitrator had acted outside his jurisdiction, as Mr. Justice Bowen had held, but on the grounds that the arbitrator was wrong in law in holding that the facts supported a promissory estoppel.

In the $A U P E$ case, the arbitrators would have applied a promissory estoppel, but held that Mr. Justice Bowen's judgment in the Smoky River case (the appeal not then having been decided) prevented them from doing so. They found for the employer. The Queen's Bench granted certiorari on the grounds that the arbitrators had committed a jurisdictional error by determining that they were without jurisdiction to apply the doctrine of promissory estoppel.

In the Court of Appeal, Mr. Justice Belzil referred to Mr. Justice Stevenson's "grave reservations" in the Smoky River case. He then held that it could not be said that the union or the employees were induced to alter their position in reliance on a promise made by the employer, from which it follows that in his view the grounds for a promissory estoppel had not been made out. He then went on:

\footnotetext{
While the Board may have erred in its conception of the principles of promissory estoppel, and may have erred in feeling bound by the prior decision of Bowen, J., yet its ultimate conclusion in refusing to apply promissory estoppel was correct because the facts before it could not support estoppel.

In these circumstances, the discretion of the learned chambers judge was wrongly exercised because the dismissal or [sic] the grievance by the Board was correct, albeit for the wrong reasons, and it was futile to remit the matter to the Board for consideration of promissory estoppel.
}

It will be seen that Mr. Justice Belzil did not say in so many words that the arbitrators would have had jurisdiction to apply a promissory estoppel if one had been supported by the facts. His use of the words "may have erred" in the first paragraph quoted above left open the possibility that the arbitrators may not have erred in feeling bound by Mr. Justice Bowen's decision that arbitrators have no such jurisdiction. However, the second paragraph extinguished that possibility. The words "albeit for the wrong reasons" clearly mean that in his view the reason given by the Board was wrong. Since the reason which was given by the Board was that the Board had no jurisdiction, it follows that, in Mr. Justice Belzil's view, the Board did have jurisdiction.

This account shows that the two decisions of the Court of Appeal have three deficiencies as authority for the proposition that an arbitrator in a private non-labour arbitration is entitled to apply a promissory estoppel. The first is that the decisions involved labour arbitrations and it could be that different rules apply to private non-labour arbitrations. The second is that everything the court said about the arbitrator's power to apply a promissory estoppel was obiter dictum because the actual decision in each case was that the facts did not give rise to a promissory estoppel. The third is that the court did not in either decision say in so many words that an arbitrator has the jurisdiction to apply a promissory estoppel, and, indeed in one of the two decisions it expressly refrained from stating a conclusion about the point. Nevertheless, the suggestion that, at least in labour arbitrations, an arbitrator may have the jurisdiction is very strong and one to be disregarded at peril. 
That leaves the question whether the views of the Court of Appeal can be transported into a private non-labour arbitration. It seems likely that they can. Different considerations may apply, on the one hand, to an arbitration which is based entirely upon an agreement by the parties to go to arbitration, and, on the other, to an arbitration which, as in the Smoky River and AUPE cases, is entered into under a legislative scheme for dealing with labour relations. However, there seems to be no dominant consideration which would suggest that, if an arbitrator acting under a labour relations statute should be able to apply a doctrine of equity in order to prevent injustice, a non-labour arbitrator should not also be able to do so.

There remains a difficulty. It is that an arbitrator in a private non-labour arbitration has jurisdiction only over the dispute referred to the arbitrator and that the dispute so referred may not be defined broadly enough to include the promissory estoppel.

Suppose, for example, that an arbitration clause refers to arbitration all disputes which may arise under a contract. ${ }^{4}$ Suppose further that in the arbitration Party A establishes that Party B has by his conduct led Party A to believe that Party B will not strictly enforce his rights under the contract and that Party $A$ has changed his position on the strength of his belief. A court might apply a promissory estoppel under those circumstances. But is a dispute which arises in part under Party B's post-contract conduct a dispute which arises under the contract? A promissory estoppel changes the legal relations of the parties established by the contract, so that the wording of the arbitration clause may not give the necessary jurisdiction to the arbitrator. In the Smoky River case', Mr. Justice Stevenson raised, without discussing, a concern which is somewhat similar in that it relates to the relationship between a contract and facts which give rise to a promissory estoppel. If the arbitrator was correct in finding that the employer was bound by the practice in question in that case, there would in his view still be an issue whether the arbitrator's determination would be precluded by the Labour Relations Act provision which prohibits arbitrators from altering, amending or changing the terms of a collective agreement.

The existence of such doubts means that the lot of an arbitration litigant who wants to claim the benefit of a promissory estoppel may not be a happy one. Unless the arbitration agreement is clear, he runs the risk that either the arbitrator or the court will hold that the arbitrator has no jurisdiction to apply the promissory estoppel, in which event the litigant may be able to resist the enforcement of the award or obtain some sort of declaratory and injunctive relief, but will be at considerable risk of being unable to obtain the advantage of the estoppel. He may try to avoid that risk by trying to have the jurisdictional question settled in advance - by special case or declaratory action, for example - but again, his tactical problems will be difficult and may prove insurmountable.

4. Mustill and Boyd, Commercial Arbitration, 1982, at pages $85-86$, suggest that an agreement to submit all disputes "arising out of" a contract includes a dispute as to whether the contract has been varied or replaced, but that an agreement to submit all disputes "under" a contract may be narrower.

5. Supra, note $1,42$. 
Principle suggests that a litigant's legal rights should not be different merely because he appears before an arbitrator rather than a superior court. It therefore suggests that an arbitrator should be able to apply a promissory estoppel if a court would be able to do so in the same dispute. But the arbitration agreement will have to be broad enough to include a dispute which is based both on the contract - promissory estoppel arises only in a contractual setting - and upon the subsequent conduct which gives rise to the promissory estoppel. 